\title{
Correlation of increased CXCL13 with intrathecal humoral immune responses to HTLV-1 in CSF of patients with HAM/TSP
}

\author{
Yoshimi Enose-Akahata, Raya Massoud, Jussi O Virtanen, Steven Jacobson ${ }^{*}$
}

From 16th International Conference on Human Retroviruses: HTLV and Related Viruses

Montreal, Canada. 26-30 June 2013

Intrathecal antibody synthesis is a well-documented phenomenon in infectious neurological diseases as well as in demyelinating diseases. Intrathecal antibody synthesis against HTLV-1 has been reported in HAM/TSP, but little is known about the role of B cells and humoral immune responses in the central nervous systems (CNS) of HAM/TSP patients. Here we demonstrate profiles of HTLV-1-specific antibodies in cerebrospinal fluid (CSF) of HAM/TSP patients. Of $36 \mathrm{HAM} / \mathrm{TSP}$ patients, antibody responses against Gag and Tax were detected in CSF of all the patients. CSF/Serum antibody ratio was elevated in anti-Gag (mean 1.20) more than in anti-Tax (mean 0.85 ), but importantly HAM/TSP patients with lesions or atrophy in spinal cord showed higher CSF/ Serum anti-Gag antibody ratio. Antibody response against Env was detected in CSF of $94.4 \%$ of patients, but CSF/ serum anti-Env ratio was significantly lower than those of anti-Gag and anti-Tax (mean 0.18). 19 patients were further studied for oligoclonal band (OCB) specificity to HTLV-1 antigens and all of them were found to have bands specific for at least one antigen studied. Significantly higher proportion of patients had Gag- or Envspecific OCBs than Tax-specific OCBs. Interestingly, CXCL13 (B cell attracting chemokine-1) was increased in CSF of HAM/TSP patients, which was associated with higher HTLV-1-specific antibody responses in CSF and was correlated with decrease of plasma blasts in peripheral blood. These results highlight the importance of the B cell compartment in HAM/TSP where production of HTLV-1-specific antibody may be required to control

\footnotetext{
*Correspondence: JacobsonS@ninds.nih.gov

Viral Immunology Section, Neuroimmunology Branch, National Institute of Neurological Disorders and Stroke, National Institutes of Health, Bethesda, MD, USA
}

() 2014 Enose-Akahata et al; licensee BioMed Central Ltd. This is an Open Access article distributed under the terms of the Creative Commons Attribution License (http://creativecommons.org/licenses/by/2.0), which permits unrestricted use, distribution, and reproduction in any medium, provided the original work is properly cited. The Creative Commons Public Domain Dedication waiver (http://creativecommons.org/publicdomain/zero/1.0/) applies to the data made available in this article, unless otherwise stated. and take full advantage of:

- Convenient online submission

- Thorough peer review

- No space constraints or color figure charges

- Immediate publication on acceptance

- Inclusion in PubMed, CAS, Scopus and Google Scholar

- Research which is freely available for redistribution

Submit your manuscript at Submit your manuscript at C BioMed Central 